\title{
HUBUNGAN KESETARAAN GENDER DENGAN USAHA MENURUNKAN ANGKA KEMATIAN BAYI DAN MENINGKATKAN KESEHATAN IBU
}

\author{
Royhanun Athiyyah \\ Univesitas Islam Negeri (UIN) Syarif Hidayatullah Jakarta \\ tiaroyhanun@gmail.com
}

\begin{abstract}
Abstrak: Karya tulis ini dibuat dengan mengkaji ketercapaian target pembangunan milenium 2015 atau Millenium Development Goals 2015 (MDGs 2015). Pembahasan selanjutnya hanya dikhususkan pada tiga target yaitu target mendorong kesetaraan gender dan pemberdayaan perempuan, menurunkan angka kematian anak, serta meningkatkan kesehatan ibu. Karya tulis ini mengacu pada dua sumber utama yaitu laporan pencapaian tujuan pembangunan milenium di Indonesia 2014 dan pembangunan kesetaraan gender background study RPJMN III (2015-2019). Target mendorong kesetaraan gender dan pemberdayaan perempuan dalam bidang pendidikan, ketenagakerjaan, dan politik secara keseluruhan tercapai. Berdasarkan survei tahun 2014, empat indikator kesetaraan gender bidang pendidikan telah melampaui target MDGs 2015 yang seharusnya yaitu 100\% (tidak ada ketimpangan pendidikan antara perempuan dan laki-laki). Hal tersebut mengindikasikan bahwa tujuan yang dilakukan menyebabkan ketimpangan pendidikan antara perempuan dan laki-laki dimana perempuan berada pada posisi yang lebih baik namun ketimpangan tersebut tidak terlalu besar. Ketercapaian yang luar biasa ini tidak diiringi ketercapaian target menurunkan angka kematian anak dan meningkatkan kesehatan ibu. Laporan terakhir mengenai indikator angka kematian anak (tahun 2012) masih berstatus akan tercapai' dan 'perlu perhatian khusus'. Hal tersebut juga terjadi pada target meningkatkan kesehatan ibu. Hal ini menunjukkan bahwa angka kematian anak dan kesehatan ibu tidak banyak dipengaruhi oleh kesetaraan gender dan pemberdayaan perempuan.
\end{abstract}

Kata Kunci: kesetaraan gender, angka kematian anak, kesehatan ibu

\section{Pendahuluan}

Kesetaraan gender dan pemberdayaan perempuan merupakan masalah yang cukup pelik yang pernah terjadi di Indonesia dalam rentang waktu yang cukup lama. Masalah kesetaraan gender ini terutama terjadi pada masa penjajahan. Perempuan pada umumnya hanya dididik untuk menjadi seorang istri yang hanya bekerja di dapur dan mengurus anak. Pendidikan hanya untuk kaum laki-laki. Hanya segelintir penduduk pribumi yang memahami pentingnya pendidikan, tidak hanya bagi laki-laki namun juga bagi perempuan.
Beruntungnya, Indonesia masih mempunyai perempuan-perempuan pribumi yang memahami pentingnya pendidikan dan mau berjuang untuk memenuhi hak dirinya dan para perempuan lainya dalam memperoleh pendidikan, salah satunya adalah Dewi Sartika pejuang emansipasi wanita dari Jawa Barat.

Selain itu, Indonesia juga memiliki masalah dalam angka kematian anak yang tinggi serta kesehatan ibu yang rendah. Berdasarkan data terakhir, angka kematian ibu masih tinggi yaitu sebesar 359 per 100.000 kelahiran hidup. Data tersebut menunjukkan keselamatan 
perempuan selama proses melahirkan masih rendah.

Indonesia bersama 189 negara Perserikatan Bangsa-bangsa (PBB) lainnya sejak September 2000 mencanangkan tujuan pembangunan millennium 2015 atau Millennium Development Goals 2015 (MDGs) di mana tiga tujuan tersebut antara lain menurunkan angka kematian anak, meningkatkan kesehatan ibu, dan mendorong kesetaraan gender dan pemberdayaan perempuan. Dalam artikel ini akan dibahas lebih lanjut mengenai hubungan kesetaraan gender dengan angka kematian ibu dan anak dalam proses melahirkan. lain:

Beberapa pertanyaan yang muncul, antara

1. Apakah ada hubungan antara kesetaraan gender dengan usaha meningkatkan angka kesehatan ibu (AKA) dan menurunkan angka kematian bayi (AKB)?

2. Jika ada, kesetaraan gender dalam bidang apa yang mempengaruhi usaha meningkatkan angka kesehatan ibu (AKA) dan menurunkan angka kematian bayi $(\mathrm{AKB})$ ?

Penelitian ini bertujuan untuk mengetahui ada atau tidaknya hubungan kesetaraan gender dengan usaha meningkatkan angka kesehatan ibu (AKA) dan menurunkan angka kematian bayi (AKB), serta untuk mengetahui faktor-faktor yang mempengaruhi usaha meningkatkan angka kesehatan ibu (AKA) dan menurunkan angka kematian bayi (AKB) dalam kaitannya dengan kesetaraan gender.

Penelitian ini bermanfaat untuk memberikan sumbangan terhadap perkembangan ilmu keluarga dan untuk memberikan sedikit informasi mengenai faktor-faktor yang mempengaruhi usaha meningkatkan angka kesehatan ibu (AKA) dan menurunkan angka kematian bayi (AKB) dalam kaitannya dengan kesetaraan gender berdasarkan sumber-sumber resmi dan pemikiran penulis .

\section{Kajian Pustaka}

Bidang pembangunan kesehatan sangat luas aspek dan cakupannya. Oleh karena itu, sebagai salah satu bidang prioritas dalam peningkatan kesetaraan gender dalam kajian ini, hanya difokuskan pada masalah terkait pencapaian Target Pembangunan Milenium (Millenium Development Goals-MDGs) 2015. Dalam MDGs, terdapat tiga target yang berkaitan langsung dengan bidang kesehatan, yaitu menurunkan angka kematian anak (target keempat), meningkatkan kesehatan ibu (target kelima), dan menanggulangi HIV/AIDS, malaria, dan penyakit menular lainnya (target keenam). Dari ketiga target tersebut, fokus kajian lebih menyempit lagi pada: a) menurunkan angka kematian ibu; b) menurunkan angka kematian balita. (RPJMN) (Bappenas, 2013). Dalam proses pencapaian $M D G s$, kesetaraan gender dan pemberdayaan perempuan yang ditinjau antara lain pada bidang pendidikan, ketanagakerjaan, dan politik. Peningkatan kesehatan ibu di Indonesia, yang merupakan Tujuan Pembangunan Milenium (MDGs) kelima, berjalan lambat dalam beberapa tahun terakhir. Rasio kematian ibu, yang diperkirakan sekitar 228 per 100.000 kelahiran hidup, tetap tinggi di atas 200 selama dekade terakhir, meskipun telah dilakukan upaya-upaya untuk meningkatkan pelayanan kesehatan ibu. Hal ini bertentangan dengan negara-negara miskin di sekitar Indonesia yang menunjukkan peningkatan lebih besar pada MDG kelima (UNICEF Indonesia, 2012). Berikut adalah tabel Angka Kesehatan Ibu dengan beberapa indikator: 


\section{4-160 | HARKAT: Media Komunikasi Islam Tentang Gender dan Anak, 12 (2), 2016}

Tabel 1. Menghilangkan Ketimpangan Gender di Tingkat Pendidikan Dasar dan Lanjutan pada Tahun 2005, dan di Semua Jenjang Pendidikan Tidak Lebih dari Tahun 2015

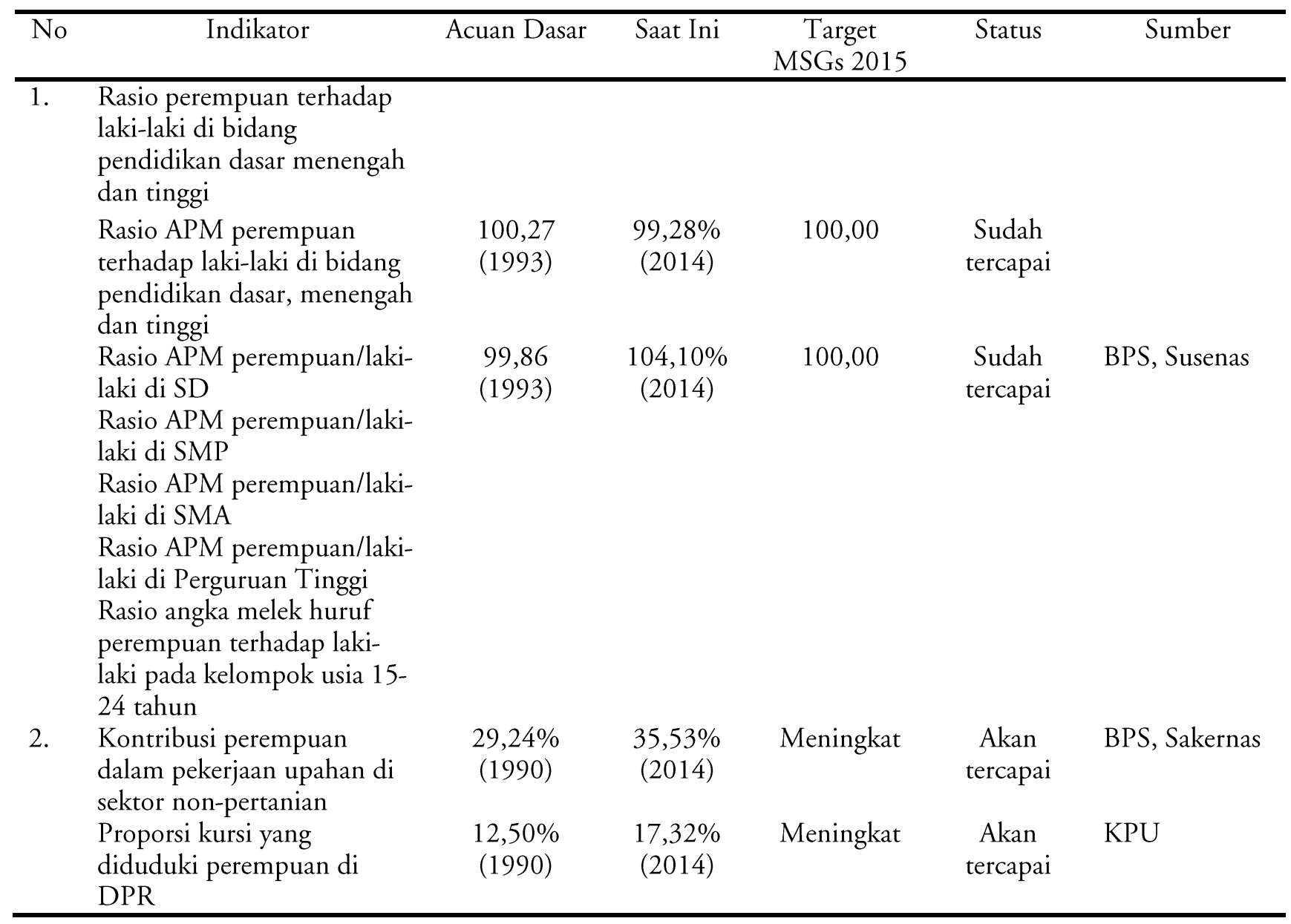

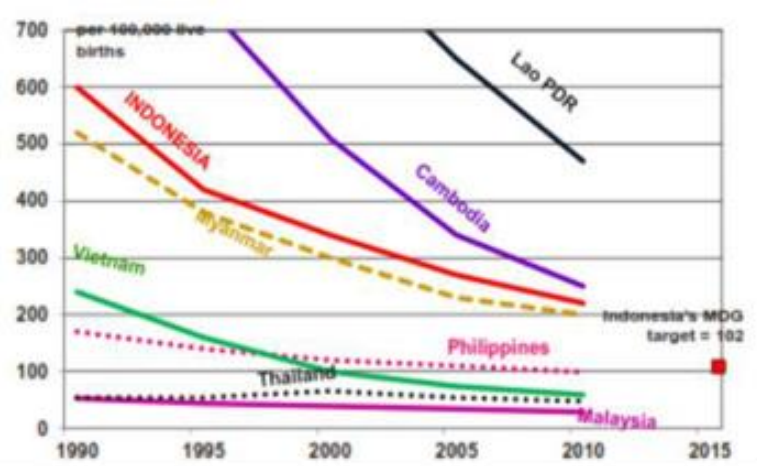

Gambar 1. Tren kematian Ibu, beberapa negara ASEA Sumber: UN Maternal Mortality Estimation Group: WHO, UNICEF, UNFPA, World Bank

Upaya keras untuk mencapai salah satu sasaraan MDGs yaitu Angka Kematian Ibu (AKI) dengan target 102 per 100.000 kelahiran hidup pada tahun 2015 telah dilakukan. Pada tahun 1991 Angka kematian ibu menurun dari 390 menjadi 228 per 100.000 kelahiran hidup pada tahun 2007 dan meningkat kembali pada tahun 2012 menjadi 359 per 100.000 kelahiran hidup (Bappenas, 2015).

Terdapat perbedaan definisi AKI pada SDKI 2012 yaitu "kematian oleh sebab apapun yang terjad isaat kehamilan, selama persalinan atau dalam waktu 2 bulan setelah persalinan", untuk menyesuaikan dengan kecilnya jumlah yang hanya mencatat 92 kematian. Sementara definisi kematian ibu mencakup kematian saat kehamilan, persalinan dan dalam waktu 42 hari pasca persalinan. Namun demikian, penggunaan definisi ini dianggap tidak akan menyebabkan over-reported kematian ibu, karena sebagian besar kematian perempuan dalam periode umur tersebut disebabkan oleh sebab maternal, sementara kematian maternal lebih cenderung 
under-reported. Selain itu, sampel SDKI 2012 adalah semua perempuan umur 15-49 tahun, baik yang kawin atau tidak kawin, sementara sampel SDKI 2007 hanya perempuan umur 1549 tahun yang pernah kawin. Kenaikan AKI sesungguhnya konsisten dengan kenaikan kematian perempuan dewasa di Indonesia. Salah satu cara yang paling efektif untuk menurunkan angka kematian ibu adalah dengan meningkatkan pertolongan persalinan oleh tenaga kesehatan terlatih (Bappenas, 2015).

Indonesia telah melakukan upaya yang jauh lebih baik dalam menurunkan angka kematian pada bayi dan balita, yang merupakan MDG keempat walaupun belum ada laporan akhir pencapaian tujuan pembangunan milenium 2015 yang secara resmi pada situs http://sekretariatmdgs.or.id. Tahun 1990-an menunjukkan perkembangan tetap dalam menurunkan angka kematian balita, bersamasama dengan komponen-komponennya, angka kematian bayi dan angka kematian bayi baru lahir.

Seperti yang sudah dilaporkan pada laporan pencapaian tujuan pembangunan Milenium di tahun 2013 bahwa angka kematian balita $(\mathrm{AKBa})$ telah turun secara bermakna dari 97 per 1000 kelahiran hidup pada tahun 1991 menjadi 40 per 1000 kelahiran hidup pada tahun 2012. Berbagai upaya telah dilakukan untuk mencapai target MDG 4 sebesar 32 per 100 kelahiran hidup. Angka kematian bayi (AKB) turun dari 68 per 1000 kelahiran hidup pada tahun 1991 menjadi 34 per 1000 kelahiran hidup pada tahun 2012, sedangkan target MDGs yang harus dicapai adalah 23 per 1000 kelahiran hidup. Sementara itu angka kematian neonatal (AKN) dari tahun 1991 sampai dengan tahun

Tabel 2. Angka Kematian Ibu hingga Tiga Per Empat dalam Kurun Waktu 1990-2015 dan Akses Kesehatan Reproduksi bagi Semua pada Tahun 2015

\begin{tabular}{|c|c|c|c|c|c|c|}
\hline No. & Indikator & $\begin{array}{c}\text { Acuan } \\
\text { Dasar }\end{array}$ & Saat Ini & $\begin{array}{c}\text { Target MDGs } \\
2015\end{array}$ & Status & Sumber \\
\hline \multicolumn{7}{|c|}{ Target A : Menurunkan Angka Kematian Ibu hingga tiga per empat dalam kurun waktu 1990-2015 } \\
\hline \multicolumn{2}{|c|}{$\begin{array}{l}\text { 1. Angka Kematian Ibu per } 100.000 \\
\text { kelahiran hidup }\end{array}$} & $390(1991)$ & $359(2012)$ & 102 & $\begin{array}{l}\text { Perlu } \\
\text { perhatian } \\
\text { khusus }\end{array}$ & $\begin{array}{l}\text { BPS, SDKI } \\
\text { *BPS, }\end{array}$ \\
\hline & $\begin{array}{l}\text { Proporsi kelahiran yang ditolong } \\
\text { tenaga kesehatan terlatih }\end{array}$ & $\begin{array}{l}40,70 \% \\
(1992)^{*}\end{array}$ & $\begin{array}{l}86,89 \% \\
(2014)^{*}\end{array}$ & Meningkat & Akan tercapai & Susenas \\
\hline \multicolumn{7}{|c|}{ Target B : Mewujudkan akses kesehatan reproduksi bagi semua pada tahun 2015} \\
\hline 3. & $\begin{array}{l}\text { Pemakaian kontrasepsi (CPR) bagi } \\
\text { perempuan menikah usia } 15-49 \\
\text { tahun, semua cara }\end{array}$ & $\begin{array}{l}49,70 \% \\
(1991)\end{array}$ & $\begin{array}{l}61,17 \% \\
(2014)^{*}\end{array}$ & Meningkat & Akan tercapai & $\begin{array}{l}\text { BPS, SDKI } \\
\text { *BPS, }\end{array}$ \\
\hline 3.a & $\begin{array}{l}\text { Pemakaian kontrasepsi (CPR) bagi } \\
\text { perempuan menikah usia 15-49 } \\
\text { tahun, cara modern }\end{array}$ & $\begin{array}{l}47,10 \% \\
(1991)\end{array}$ & $\begin{array}{l}60,18 \% \\
(2014)^{*}\end{array}$ & Meningkat & Akan tercapai & $\begin{array}{l}\text { Susenas } \\
{ }^{* *} \text { Keme nkes } \\
\text { RI }\end{array}$ \\
\hline & $\begin{array}{l}\text { Angka kelahiran remaja (perempuan } \\
\text { usia } 15-19 \text { tahun) per } 1000 \\
\text { perempuan usia } 15-19 \text { tahun }\end{array}$ & $\begin{array}{c}67 \\
(1991)\end{array}$ & $\begin{array}{c}48 \\
(2012)\end{array}$ & Menurun & Akan tercapai & \\
\hline \multicolumn{7}{|c|}{$\begin{array}{l}\text { 5. Cakupan pelayanan Antenatal } \\
\text { (sedikitnya } 1 \text { kali kunjungan dan } 4 \\
\text { kali kunjungan) }\end{array}$} \\
\hline & -1 kunjungan & $\begin{array}{c}75,00 \% \\
(1991)\end{array}$ & $\begin{array}{l}93,76 \% \\
(2014)^{* *}\end{array}$ & Meningkat & Akan tercapai & \\
\hline & -4 kunjungan & $\begin{array}{l}56,00 \% \\
(1991)\end{array}$ & $\begin{array}{l}85,72 \% \\
(2014)^{* *}\end{array}$ & & Akan tercapai & \\
\hline & $\begin{array}{l}\text { Unmeet Need (kebutuhan } \\
\text { keluarga berencana/KB yang tidak } \\
\text { terpenuhi) }\end{array}$ & $\begin{array}{c}12,70 \% \\
(1991)\end{array}$ & $\begin{array}{c}11,40 \% \\
(2012)\end{array}$ & Menurun & Akan tercapai & \\
\hline
\end{tabular}


Tabel 3. Menurunkan Angka Kematian Balita (AKBa) Hingga Dua Per Tiga Dalam Kurun Waktu 1990-2015

\begin{tabular}{|c|c|c|c|c|c|c|}
\hline No. & Indikator & $\begin{array}{l}\text { Acuan } \\
\text { Dasar }\end{array}$ & Saat Ini & $\begin{array}{c}\text { Target MDGs } \\
2015 \\
\end{array}$ & Status & Sumber \\
\hline 1. & $\begin{array}{l}\text { Angka Kematian Balita } \\
\text { (AKBa) per } 1000 \\
\text { kelahiran hidup }\end{array}$ & $\begin{array}{c}97 \\
(1991)\end{array}$ & $40(2012)$ & 32 & $\begin{array}{l}\text { Perlu perhatian } \\
\text { khusus }\end{array}$ & $\begin{array}{l}\text { BPS, } \\
\text { SDKI }\end{array}$ \\
\hline 2. & $\begin{array}{l}\text { Angka Kematian Bayi } \\
\text { (AKB) per } 1000 \text { kelahiran } \\
\text { hidup }\end{array}$ & $\begin{array}{c}68 \\
(1991)\end{array}$ & $32(2012)$ & 23 & $\begin{array}{l}\text { Perlu perhatian } \\
\text { khusus }\end{array}$ & \\
\hline 3. & $\begin{array}{l}\text { Angka Kematian Neonatal } \\
\text { per } 1000 \text { kelahiran hidup }\end{array}$ & $\begin{array}{c}31 \\
(1991)\end{array}$ & $19(2012)$ & Menurun & Akan tercapai & \\
\hline 4. & $\begin{array}{l}\text { Presentase anak usia } 1 \\
\text { tahun yang diimunisasi } \\
\text { campak }\end{array}$ & $\begin{array}{l}44,50 \% \\
(1991)^{*}\end{array}$ & $\begin{array}{l}89,42 \% \\
(2014)^{*}\end{array}$ & Meningkat & Akan tercapai & $\begin{array}{l}{ }^{*} \mathrm{BPS} \text {, } \\
\text { Susenas }\end{array}$ \\
\hline
\end{tabular}

2003 turun dari 32 menjadi 20 per 1000 kelahiran hidup, kemudian turun sedikit menjadi 19 per 1000 kelahiran hidup pada tahun 2007, selanjutnya tidak berubah pada tahun 2012 (Bappenas, 2015).

Apabila merujuk pada data resmi SDKI yang dimuat pada laporan MDGs tahun 2013, diperkirakan target MDGs 4 untuk $\mathrm{AKBa}$ dan AKB tidak akan tercapai. Oleh karena data terbaru yang bersumber dari SDKI 2012 dan RISKESDAS 2013 sampai saat ini belum ada pemutakhiran data, maka untuk pemutakhiran data terbaru bersumber dari laporan Kementerian Kesehatan tahun 2014 yang dimuat secara resmi di web (http:/www.gizikia.Depkes.go.id/data/publikrep ort/anaktahun?active $=80$ ) dimana dilaporkan angka Kematian Balita sebesar 9 per 1000 kelahiran hidup, Angka Kematian Bayi sebesar 8 per 1000 kelahiran hidup dan Angka Kematian Neonatal sebesar 6 per 1000 kelahiran hidup. Mengacu pada laporan tersebut maka tampaknya indikator MDGs telah mencapai target yang telah ditentukan, dimana $\mathrm{AKB}$ a di bawah 32 per 1000 kelahiran hidup dan AKB di bawah 24 per 1000 kelahiran hidup. Dengan catatan bahwa data yang berasal dari laporan rutin yang sudah dipublilkasi secara resmi harus dibaca dengan sangat hati-hati. Angka-angka dari laporan rutin ini tidak bisa dibandingkan begitu saja dengan angka hasil survey seperti SDKI yang di disain secara khusus dengan metodologi survey yang sudah baku (Bappenas, 2015).

\section{Pembahasan}

Berdasarkan tujuan penulisan karya tulis ini, penulis akan memfokuskan pokok pembahasan pada tiga target dari delapan target pembangunan milenium (Millenium Development Goals-MDGs) 2015 yaitu mendorong kesetaraan gender dan pemberdayaan perempuan, meningkatkan angka kesehatan ibu, dan menurunkan angka kematian anak.

Dari data laporan yang didapatkan melalui berbagai sumber,ketercapaian tiga target MDGs tersebut berbeda-beda. Berdasarkan data Sekretariat MDGs tahun 2014, lima indikator kesetaraan gender dan pemberdayaan perempuan berstatus telah tercapai dan dua indikator lainnya berstatus akan tercapai. Pencapaian ini menunjukkan Indonesia cukup berhasil dalam mendorong kesetaraan gender dalam focus bidangnya yaitu pendidikan, politik, dan ketenagakerjaan.

Pada bidang pendidikan kesetaraan gender diukur dengan menggunakan rasio angka 
partisipasi murni (APM) perempuan terhadap laki-laki di jenjang sekolah dasar sampai perguruan tinggi dan rasio angka melek huruf penduduk berusia 15-24 tahun. Dalam empat indikator Indonesia telah melampaui target MDGs yaitu 100\%, hal ini menunjukkan bahwa usaha meningkatkan kesetaraan perempuan dengan laki-laki melebihi dari yang seharusnya (telah terjadi ketimpangan gender dimana perempuan lebih baik) sedangkan satu indikator lainnya mendekati $100 \%$ (telah terjadi ketimpangan gender dimana laki-laki lebih baik). Walaupun begitu, hal ini merupakan pencapaian yang luar biasa karena telah mendekati target MDGs yaitu $100 \%$

Indikator kesetaraan gender dalam bidang ketenagakerjaan diukur melalui kontribusi perempuan dalam kerja upahan di sektor nonpertanian. Keterlibatan perempuan dalam kerja upahan di sektor non-pertanian yang meningkat dari 29,24 persen pada tahun 1990 menjadi 35,53 persen pada tahun 2014, sudah sesuai dengan target MDGs (meningkat tetapi masih terlalu sedikit) (Bappenas, 2015).

Pada bidang politik indikator yang digunakan untuk mengetahui keterlibatan perempuan dalam bidang pengambilan keputusan publik digunakan proporsi kursi yang diduduki perempuan di DPR. Di bidang poilitik, proporsi perempuan di DPR sudah lebih tinggi di tahun 2014 (17,30 persen) dibandingkan pada tahun 1990 (12,50 persen), sudah sesuai dengan target MDGs (meningkat tetapi belum sesuai dengan kuota yang diharapkan) (Bappenas, 2015).

Kesetaraan gender bidang lainnya yang menjadi focus pemerintah pada Pembangunan Kesetaraan Gender Background Study RPJMN III (2015-2019) adalah kesetaraan gender bidang kesehatan dan hukum. Selanjutnya hanya akan dibahas kesetaraan gender dalam bidang hokum.

Dalam bidang kesehatan, kesetaraan gender ditinjau dari angka kematian ibu (AKI) dan angka kematian bayi (AKB), angka kematian balita (AKBa), dan angka kematian neonatal $(\mathrm{AKN})$. Hal ini berhubungan dengan target MDGs keempat dan kelima yaitu menurunkan angka kematian bayi dan meningkatkan kesehatan Ibu.

Berdasarkan data yang diperoleh, AKBa per provinsi menunjukkan penurunan. Provinsi yang tetap tinggi adalah NTB (pada tahun 2002 AKBa 103, lalu turun menjadi 92 pada tahun 2007), NTT yang justru meningkat (dari 73 pada tahun 2002 menjadi 80 pada tahun 2007), dan Maluku dengan AKBa 93 pada tahun 2007 (AKBa tahun 2002 tidak tersedia). Sementara itu, Bali dan Kalimantan Selatan menunjukkan adanya peningkatan $\mathrm{AKBa}$ yang cukup menguatirkan. Provinsi Bali pada tahun 2002 telah sangat rendah yaitu 19 , namun pada tahun 2007 malah meningkat hingga 38. AKBa pada provinsi-provinsi yang baru muncul sebagai pemekaran wilayah administrasi umumnya tinggi, terutama provinsi Sulawesi Barat (96 pada tahun 2007) (Bappenas, 2013).

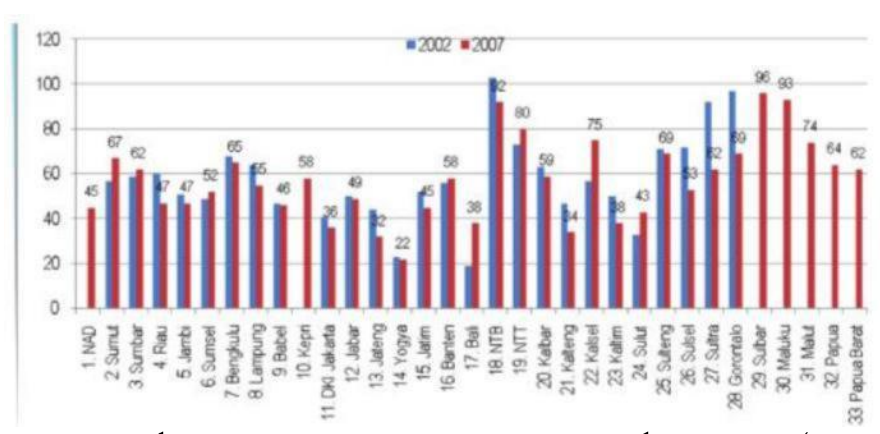

Gambar 2. Angka Kematian Balita Menurut Provinsi, 2002 dan 2007 (per 1.000 kelahiran hidup) Sumber : BPS, Survei Demografi dan Kesehatan Indonesia 2002-2007 

158-160 | HARKAT: Media Komunikasi Islam Tentang Gender dan Anak, 12 (2), 2016

Tabel 4. AKBa Berdasarkan Jenis Kelamin dan Wilayah

\begin{tabular}{|l|l|l|l|l|l|l|}
\hline \multicolumn{1}{|c|}{ Jenis Kelamin } & \multicolumn{2}{|c|}{ Tahun } & & Jenis Kelamin & Tahun \\
\hline & $2002-2003$ & 2007 & & & $2002-2003$ & 2007 \\
\hline Laki-laki & 58 & 56 & & Perdesaan & & \\
\hline Perempuan & 51 & 46 & & Perkotaan & & \\
\hline
\end{tabular}

Sumber: BPS, Survei Demografi dan Kesehatan Indonesia 2002-2007

Bila melihat berdasarkan jenis kelamin, maka AKBa laki-laki lebih tinggi daripada perempuan. Pada tahun 2002 AKBa laki-laki 58 dan menurun pada tahun 2007 menjadi 56 per 1.000 kelahiran hidup. Sedangkan AKBa perempuan 51 dan menurun pada tahun 2007 menjadi 46 per 1.000 kelahiran hidup. Dengan demikian, dapat dikatakan bahwa balita laki-laki lebih rentan untuk meninggal dibandingkan balita perempuan. AKBa di perdesaan lebih tinggi dibandingkan di perkotaan. Dengan demikian, bisa diasumsikan bahwa balita laki-laki di perdesaan adalah yang paling rentan untuk meninggal (Bappenas, 2013).

Menurut Laporan Capaian MDGs Indonesia 2011 yang disusun oleh Bappenas, kematian balita terutama disebabkan oleh diare dan pneumonia, serta terkait erat dengan masalah gizi (gizi buruk dan gizi kurang) (Bappenas, 2013). Hal ini dapat disimpulkan bahwa kematian balita disebabkan oleh lingkungan yang tidak bersih dan sanitasi yang buruk.

Berdasarkan sumber yang penulis baca, faktor penyebab angka kematian balita laki-laki lebih tinggi daripada perempuan antara lain akibat pemahaman gizi dan kesehatan yang rendah dari orang tua. Bayi dan balita yang sedang dalam masa pertumbuhan membutuhkan energy yang lebih besar serta energi tambahan untuk menjaga kestabilan tubuh mereka. Sedangkan balita laki-laki membutuhkan lebih banyak energy dibandingkan bayi perempuan karena metabolism bayi laki-laki lebih cepat dibandingkan metabolisme bayi perempuan. Namun kebanyakan orang tua tidak mengetahui hal ini. Sehingga, dengan asupan gizi yang sama, maka balita perempuan lebih optimal pertumbuhannya dibandingkan balita laki-laki. Dalam keluarga miskin, dengan keterbatasan ketersediaan makanan, balita laki-laki akan cenderung mendapat asupan gizi yang kurang dari memadai untuk pertumbuhannya. Sebagai akibatnya, balita laki-laki pada rumah tangga miskin cenderung mengalami gizi kurang dan bahkan gizi buruk. Bila bayi atau balita laki-laki gizi buruk mengalami diare, maka defisit energinya semakin bertambah tinggi, yang kemudian memperparah pertahanan tubuhnya yang telah rentan.

Kesetaraan gender yang berperan untuk meningkatkan kesehatan Ibu selama proses kehamilan hingga melahirkan adalah kesetaraan gender dalam bidang pendidikan dan kesehatan itu sendiri. Kesetaraan gender dalam bidang pendidikan sudah tercapai bahkan perempuan berada dalam posisi yang lebih baik di beberapa indikator. Namun ketercapaian tersebut tidak diikuti oleh penurunan angka kematian bayi dan peningkatan kesehatan ibu.

Dari data grafik di bawah ini, terlihat bahwa ibu yang meninggal karena melahirkan sebagian besar (65,2 persen) berusia antara 20 sampai dengan 35 tahun, diikuti oleh ibu berusia di atas 35 tahun. Persentase kematian terbesar berdasarkan urutan anak yang dilahirkan adalah saat melahirkan anak pertama, yaitu mencapai 45,6 persen. Dari sisi pendidikan ibu, 60,9 persen ibu yang meninggal karena melahirkan berpendidikan SD atau tidak sekolah. Nampaknya, semakin rendah pendidikan yang dimiliki, semakin besar resiko meninggal saat melahirkan. Resiko meninggal saat melahirkan juga lebih besar bagi yang ibu yang tinggal di perdesaan dibandingkan di perkotaan, sebab persentase ibu meninggal lebih besar di 
perdesaan. Dengan demikian, untuk pencegahan kematian bagi ibu melahirkan perhatian khusus perlu diberikan pada wanita yang baru menikah dan ibu-ibu yang hamil pertama kali, yang berada di perdesaan, yang berpendidikan SD dan sekolah menengah (Bappenas, 2013).

Pendidikan ibu sangat berpengaruh dalam kesehatan ibu selama kehamilan dan proses melahirkan. Target ketiga MDGs yaitu mendorong kesetaraan gender dan pemberdayaan perempuan sudah tercapai khususnya di bidang pendidikan. Ini menunjukkan bahwa perempuan di Indonesia sudah mendapatkan pendidikan yang lebih baik dibandingkan pada tahun-tahun sebelumnya. Namun, target keempat dan kelima MDGs yaitu menurunkan angka kematian bayi dan meningkatkan kesehatan ibu belum belum mencapai target yang ditentukan dalam MDGs. Hal ini menunjukkan bahwa peningkatan pendidikan untuk kaum perempuan tidak linear dengan penurunan angka kematian bayi maupun angka kematian anak. Hal tersebut terjadi karena terdapat factor-faktor lain yang mempengaruhi tercapainya target keempat dan kelima tersebut. Faktor-faktor tersebut salah satunya adalah tenaga kesehatan terdidik.
Menurut analisis data SDKI per propinsi di Indonesia, peningkatan cakupan persalinan tenaga kesehatan di Indonesia memiliki kontribusi 45 persen untuk menentukan angka kematian ibu. Peningkatan proporsi persalinan oleh tenaga kesehatan terlatih sudah semakin meningkat, dari tahun 1995 yang hanya 46,13 persen menjadi 81,25 persen. Namun, data dari Riset Kesehatan Dasar (Riskesdas) Kemenkes tahun 2010 menunjukkan bahwa persalinan di fasilitas kesehatan masih sekitar 55,40 persen (Bappenas, 2013). Tenaga kesehatan terdidik juga hanya terpusat di daerah perkotaan saja dan hanya sebagian kecil yang bertahan di daerah terpencil seperti Papua.

\section{Simpulan}

Kesetaraan gender dan pemberdayaan perempuan dalam beberapa bidang mempengaruhi angka kematian anak dan kesehatan ibu. Hal ini dibuktikan dengan peningkatan kesetaraan gender dan pemberdayaan perempuan yang diiringi dengan menurunnya angka kematian anak dan kematian ibu saat proses kehamilan hingga melahirkan (walaupun tidak secara linear).

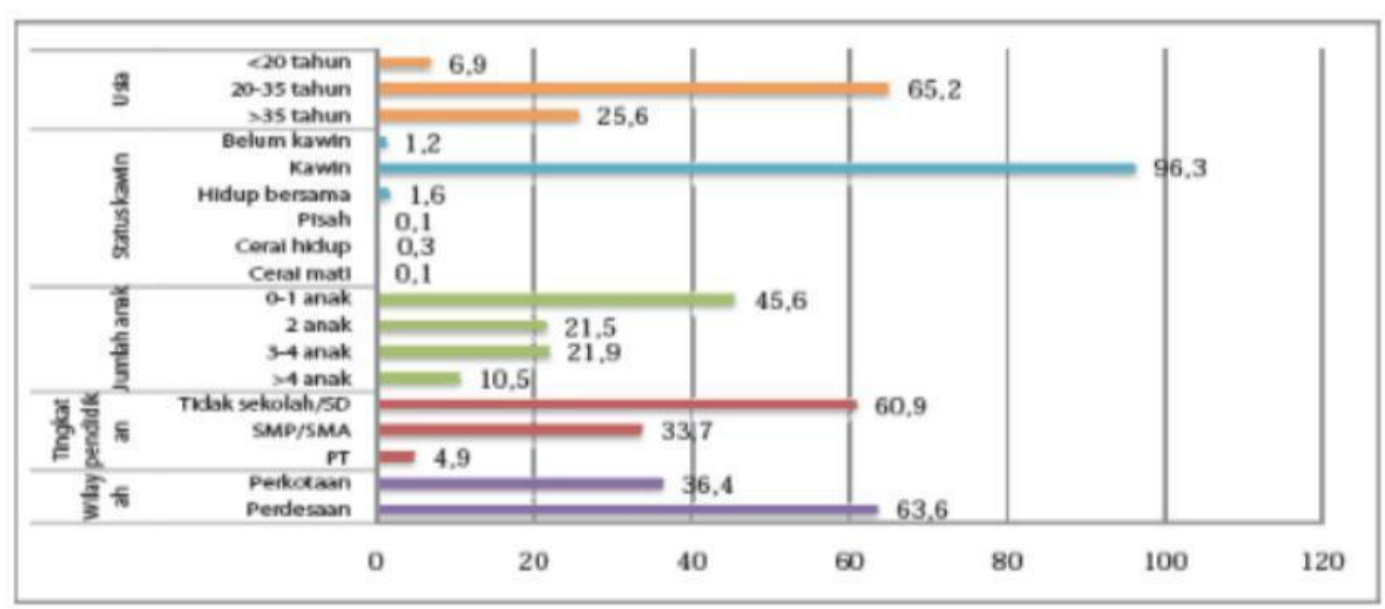

Gambar 3. Karakteristik Ibu Meninggal

Sumber: Kajian Lanjut hasil SP 2010 - Kemenkes 
Kesetaraan gender dan pemberdayaan perempuan dalam bidang pendidikan sangat berpengaruh dalam usaha menurunkan angka kematian anak dan meningkatkan kesehatan ibu. Berdasarkan data yang diperoleh Bappenas, semakin rendah pendidikan ibu, semakin besar resiko meninggal saat melahirkan. Walaupun kesetaraan gender dalam bidang pendidikan telah mencapai target namun target keempat dan kelima MDGs (menurunkan angka kematian anak dan meningkatkan kesehatan ibu) belum mencapai target. Hal ini menunjukkan bahwa peningkatan pendidikan dan pemerdayaan perempuan hanya menjadi salah satu faktor yang mempengaruhi angka kematian anak dan kesehatan ibu. Meskipun pendidikan dan pemberdayaan perempuan meningkat, namun pengetahuan ibu mengenai kehamilan, proses melahirkan, dan gejala-gejala komplikasi persalinan masih rendah. Faktor lain yang mempengaruhi angka kematian anak dan kesehatan ibu adalah tenaga kesehatan terlatih yang masih terpusat di daerah-daerah tertentu dan fasilitas kesehatan yang belum mencapai daerah-daerah terpencil.

\section{Daftar Pustaka}

Direktorat Kependudukan, Pemberdayaan Perempuan, dan Perlindungan Anak. 2013.

Pembangunan Kesetaraan Gender Background Study RPJMN II (2015-2019). Jakarta: BAPPENAS.

Kementerian Perencanaan Pembangunan

Nasional/ Badan Perencanaan

Pembangunan Nasional (BAPPENAS).

2015. Laporan Pencapaian Tujuan

Pembangunan Milenium di Indonesia 2014. Jakarta: BAPPENAS.

UNICEF Indonesia. 2012. Ringkasan Kajian Kesehatan Ibu \& Anak. Jakarta: UNICEF Indonesia. 